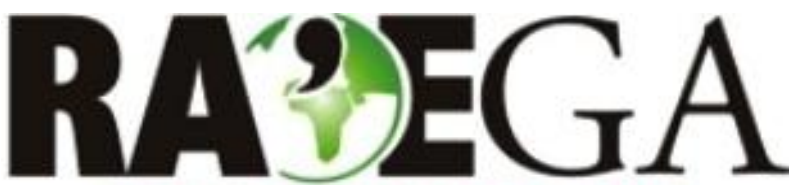

O ESPAÇO GEOGRÁFICO EM ANÁLISE

\title{
ARTICULAÇÕES ENTRE O ESTADO E O COOPERATIVISMO AGRÍCOLA: UM ESTUDO SOBRE AS COOPERATIVAS DE IMIGRANTES HOLANDESES NOS CAMPOS GERAIS DO PARANÁ
}

\section{ARTICULATIONS BETWEEN THE STATE AND AGRICULTURAL COOPERATIVISM: A STUDY ON DUTCH IMMIGRANT COOPERATIVES IN THE CAMPOS GERAIS OF PARANÁ}

\author{
Bruno Bonsanto Dias ${ }^{1}$, Sergio Fajardo ${ }^{2}$
}

\section{RESUMO}

O cooperativismo agropecuário brasileiro apresenta historicamente uma intrínseca relação com o Estado. Pode-se afirmar que esse vínculo se sustenta através de políticas públicas aplicadas a este setor. Nesse trabalho são demonstradas como as articulações políticas entre o Estado e três cooperativas agropecuárias do Paraná (Batavo/Frísia, Castrolanda e Capal), coincidiram com o processo de modernização da agricultura paranaense. Parte-se de uma abordagem histórica sobre o processo de criação e organização dessas cooperativas iniciado com a chegada de imigrantes holandeses no estado do Paraná. O recorte temporal procurou evidenciar o período pós 1990, marcado por novas estratégias de atuação de mercado e pela reestruturação produtiva dessas cooperativas. A metodologia está baseada em revisão bibliográfica sobre o cooperativismo agropecuário, a imigração holandesa no Paraná e as políticas de Estado direcionadas ao setor cooperativista. Foram consultados diversos relatórios anuais da Frísia, Batavo e Capal e realizada uma entrevista com uma instituição de pesquisa vinculada às cooperativas. O trabalho demonstrou como as estratégias de atuação das cooperativas foram estimuladas pelo Estado e como elas repercutiram sobre o território. Foi observada uma expansão horizontal de unidades produtivas em diversos municípios brasileiros, principalmente nos estados do Paraná e São Paulo. Além disso, o trabalho constatou que a reestruturação produtiva das cooperativas foi conduzida por políticas de Estado, resultando no aumento da verticalização produtiva e, consequentemente, na arrecadação das cooperativas.

Palavras chave: Cooperativismo agropecuário; Imigração holandesa; Reestruturação produtiva.

\section{ABSTRACT}

Brazilian agricultural cooperatives historically have an intrinsic relation with the State. It can be affirmed that this bond is supported by public policies applied to this sector. This study presents how the political articulations between the State and three agricultural cooperatives from Paraná (Batavo/Frísia, Castrolanda and Capal) coincides in time with the agricultural modernization process in Paraná. The study is based on a historical approach on the cooperatives process of creation and organization, which started with the arrival of Dutch immigrants in Paraná. The temporal cut aimed to highlight the period of time after 1990, which was marked by new market strategies and by the productive restructuring of these cooperatives. The methodology is based on the bibliographic review about the agricultural cooperatives, the Dutch immigration in the state of Paraná and the State policies geared towards the cooperative sector. Several annual reports from Frísia, Batavo and Capal were checked and an interview with a research institution linked to the cooperatives was conducted. The study demonstrated how the State encouraged operation strategies by the cooperatives and how they impacted on the territory. It was possible to observe a horizontal expansion of the productive units in several Brazilian municipalities, especially in the states of Paraná and São Paulo. In addition, the study concluded that the productive restructuring of the cooperatives was conducted by State policies. It resulted in the increase of productive verticalization and, consequently, in cooperative collection.

Keywords: Farming cooperatives; Dutch immigration; Productive restructuring.

\footnotetext{
${ }^{1}$ Universidade Estadual do Centro-Oeste do Paraná, Guarapuava/PR, email: brunobdias@gmail.com

${ }^{2}$ Universidade Estadual do Centro-Oeste do Paraná, Guarapuava/PR, email: sergiofajardo@hotmail.com
} 
DIAS, B. B. ,FAJARDO, S.

\section{ARTICULAÇÕES ENTRE O ESTADO E O COOPERATIVISMO AGRÍCOLA: UM ESTUDO SOBRE AS COOPERATIVAS DE IMIGRANTES HOLANDESES NOS CAMPOS GERAIS DO PARANÁ}

\section{INTRODUÇÃO}

O cooperativismo enquanto sistema de organização social surgiu no século XVIII, no contexto europeu pós Revolução Industrial. Como resposta à estrutura econômica criada na Inglaterra em seu processo de industrialização, onde os preceitos do liberalismo econômico sustentavam um cenário de competitividade entre os grupos econômicos e as classes sociais, o cooperativismo se apresentou como uma alternativa ao paradigma capitalista/liberal da época. Seus princípios norteadores eram embasados na solidariedade, liberdade, equidade e trabalho em equipe.

Devido a seu crescimento e forte presença na organização social da Europa, não foi por acaso que o cooperativismo chegou ao Brasil por intermédio das colônias de imigração europeias. O grande movimento migratório que fora planejado, subsidiado e executado pelo Estado entre as décadas de 1870 a 1930, foi responsável por deslocar cerca de 40 milhões de europeus ao Brasil. Naquela ocasião, o Estado visava promover a substituição da mão de obra escrava pela força de trabalho dos imigrantes (GONÇALVES, 2012).

Dessa forma, a influência da imigração europeia foi fundamental para o surgimento das primeiras cooperativas no Brasil. $\mathrm{Na}$ virada do século XIX para o século $X X$, começam a ser desenvolvidas as primeiras iniciativas cooperativistas no país nas colônias de imigração alemã e italiana da Região Sul. Visando superar as adversidades de aclimatação física e cultural impostas pelo processo migratório, os imigrantes europeus foram se estabelecendo em pequenas propriedades agrícolas, característica que oportunizou a organização de um sistema de trabalho em grupo e sustentou a criação das primeiras cooperativas do Brasil.

$\mathrm{Na}$ década de 1930, durante a instauração do Estado Novo, as cooperativas foram vistas como uma necessidade nacional para organizar a gestão de determinados setores produtivos (SERRA, 2013). No segmento agropecuário, especificamente, o Estado passou a utilizar o cooperativismo como mecanismo estratégico para promover a diversificação do cultivo agrícola do país (GONÇALVES, 2012). Através do Decreto no 22.239/1932, sancionado pelo presidente Getúlio Vargas, o Estado criou o primeiro marco regulatório responsável pelas bases institucionais do cooperativismo brasileiro. A partir desse momento, o Estado passou a regular e a incentivar a expansão das cooperativas, principalmente, através do mecanismo de isenção de impostos.

No ramo agropecuário, o Estado passou a incentivar a criação e o desenvolvimento das cooperativas com a implícita tática de se tornarem instrumentos de organização do sistema de produção agrícola nacional. Desde então, as cooperativas sempre contaram com um 'braço' do Estado através de suas políticas públicas para se articularem às condições estruturais "que priorizaram o econômico ao invés do social" (SCHNEIDER, 1981, p.31).

Como resultado, muitas cooperativas agropecuárias se fortaleceram econômica e infraestruturalmente enquanto agroindústrias de grande porte, o que acabou inviabilizando o princípio da participação efetiva e o controle da gestão por parte do quadro de associados (SCHNEIDER, 1981). Neste caso, "o agigantamento das cooperativas como empresas, por si só, produz como consequência o distanciamento da cooperativa nas relações com os associados, e também com os princípios ideológicos do sistema" (SERRA, 2013, p.35).

Na Região Sul do Brasil, o estado do Paraná possui um forte histórico ligado ao cooperativismo. Serra (2013, p.22) alega que "a história do cooperativismo paranaense não apresenta muitas diferenças comparada à história do cooperativismo brasileiro". Atualmente, a organização do espaço rural paranaense está fortemente influenciada por uma lógica produtiva imposta pela ação territorial de empresas multinacionais do agronegócio e de cooperativas agropecuárias (FAJARDO, 2008).

Figurando como um dos estados de maior produção agropecuária do país, as empresas multinacionais e as cooperativas agropecuárias presentes no Paraná são agentes que vêm promovendo um modelo de agricultura 


\section{ARTICULAÇÕES ENTRE O ESTADO E O COOPERATIVISMO AGRÍCOLA: UM ESTUDO SOBRE AS COOPERATIVAS DE IMIGRANTES HOLANDESES NOS CAMPOS GERAIS DO PARANÁ}

baseado na produção de commodities, visando atender as demandas do mercado global. Essa lógica tem sustentado elevados índices de produtividade e um saldo muito expressivo em termos de arrecadação por parte desses agentes.

As cooperativas paranaenses estão "entre as mais desenvolvidas do país em termos de volume de produção, transformação de matéria-prima e no número de associados", (SERRA, 2013, p.21) e, historicamente, sempre estiveram em sintonia com as estratégias e interesses do Estado. Segundo dados da Organização das Cooperativas do Paraná (OCEPAR, 2017), as 69 cooperativas agropecuárias registradas na entidade representam cerca de $56 \%$ da produção agropecuária do estado e deste percentual $48 \%$ corresponde a produtos industrializados.

Diante desse cenário, este trabalho traz algumas reflexões sobre o papel do Estado e de suas articulações com o cooperativismo agropecuário no Paraná. O trabalho analisa a trajetória de três cooperativas: Batavo/Frísia, Castrolanda e Capal; cujas origens remetem aos projetos de imigração holandesa ocorridos na mesorregião Centro Oriental do estado.

Criadas dentro de um contexto político e econômico específico, essas cooperativas construíram um forte legado cooperativista e foram responsáveis por dinamizar a conjuntura econômica e o arranjo territorial, além de se tornarem elementos importantes para a formação sócio espacial dessa região.

O principal objetivo do trabalho é demonstrar a relação entre as três cooperativas descendentes da imigração holandesa e suas articulações com políticas de crédito e financiamento, intermediadas por bancos estatais. Este mecanismo foi responsável por alinhar essas cooperativas a um perfil produtivo com altos índices de beneficiamento da produção agrícola (verticalização), equiparando-as ao modelo de produção das agroindústrias de grande porte.

Dessa forma, o trabalho destaca a atuação do Estado no processo de reestruturação produtiva das cooperativas por intermédio de uma política de financiamento que resultou num exponencial aumento de suas respectivas arrecadações.

Além disso, apresentam-se alguns mapas e tabelas que ilustram as repercussões territoriais e econômicas decorrentes dessa articulação entre as cooperativas descendentes da imigração holandesa e o Estado. Pôde-se perceber uma capilarização horizontal das unidades produtivas em diversos municípios brasileiros, principalmente nos estados do Paraná e São Paulo.

O recorte temporal se direciona ao período pós 1990, onde novas estratégias de atuação foram colocadas em prática pelas cooperativas analisadas no trabalho. Nesse período, elas iniciaram uma forte reestruturação produtiva marcada pela verticalização de diversas cadeias produtivas. A escolha desse recorte temporal se justifica pela adoção de uma postura política neoliberal que, a partir da década de 1990, trouxe um novo direcionamento para diversos setores econômicos. Fajardo (2008, p. 41) esclarece que "a agricultura, a partir da abertura econômica neoliberal, expõe-se aos ditames do mercado internacional e passa a ser orientada por lógicas externas, ou seja, do mercado global".

\section{PROCEDIMENTOS METODOLÓGICOS}

Os procedimentos metodológicos foram baseados em pesquisas de gabinete $e$ diretamente em campo. Foi realizada uma ampla revisão bibliográfica acerca do cooperativismo agropecuário no Brasil, do histórico das cooperativas de imigrantes holandeses, objetos desse estudo; além de uma breve abordagem sobre duas políticas públicas voltadas ao setor cooperativista: o Programa de Revitalização de Cooperativas de Produção Agropecuária (RECOOP) e o Programa de Desenvolvimento Cooperativo para Agregação de Valor à Produção Agropecuária (PRODECOOP).

Também foram analisados alguns relatórios anuais das cooperativas Batavo/Frísia, Capal e Castrolanda, com a finalidade de elaborar os gráficos e os mapas apresentados no trabalho. A pesquisa de campo se baseou em entrevista 


\section{ARTICULAÇÕES ENTRE O ESTADO E O COOPERATIVISMO AGRÍCOLA: UM ESTUDO SOBRE AS COOPERATIVAS DE IMIGRANTES HOLANDESES NOS CAMPOS GERAIS DO PARANÁ}

com uma instituição de pesquisa agropecuária vinculada às cooperativas.

Além disso, foram consultadas informações secundárias em instituições como a Empresa Brasileira de Pesquisa Agropecuária (EMBRAPA), o Instituto Paranaense de Desenvolvimento Econômico e Social (IPARDES) e a Organização das Cooperativas do Paraná (OCEPAR).

Primeiramente, o trabalho discute o processo de formação econômica da mesorregião Centro Oriental do Paraná onde se localiza a região conhecida como Campos Gerais. Nessa sessão, se aborda a influência da imigração holandesa e o papel das cooperativas agropecuárias para construção de uma matriz econômica regional sustentada pela agricultura e pecuária leiteira.

Em seguida, o trabalho discute o processo de modernização da agricultura nos Campos Gerais do Paraná iniciado a partir da década de 1960. Tal processo foi fortemente influenciado pelo Estado que, por sua vez, utilizou as cooperativas agropecuárias oriundas da imigração holandesa como importante vetor para a modernização agrícola da região.

Por fim, o trabalho apresenta as estratégias de atuação dessas cooperativas no período pós 1990, destacando o papel do Estado no processo de reestruturação produtiva. Nesta sessão, se destacam as consequências das políticas de crédito e financiamento como o RECOOP e o PRODECOOP para a estrutura e ação territorial das cooperativas Frísia, Castrolanda e Capal.

\section{RESULTADOS E DISCUSSÃO}

Considerações sobre a formação territorial dos Campos Gerais do Paraná

Inserida no Paraná Tradicional ${ }^{3}$, (CUNHA, 2003) a região geograficamente identificada como "Campos Gerais" se caracteriza pela

\footnotetext{
${ }^{3}$ O trabalho de Cunha (2003, p.30) parte de um princípio metodológico que identifica e define três trajetórias de desenvolvimento distintas no Paraná, as quais originaram dinâmicas de desenvolvimento diferenciadas. A partir dessas trajetórias, o autor identificou um recorte territorial ao estado do Paraná dividindo-o em: Paraná Tradicional, Paraná do Norte e Paraná do Sudoeste.
}

presença de uma paisagem peculiar. O tempo geológico dotou esta região de uma paisagem composta por elementos específicos no que se refere aos domínios biofísico e geomorfológico.

Situado na porção oriental do Segundo Planalto Paranaense, a região abrange 25 municípios e possui uma paisagem constituída, originalmente, por campos limpos e úmidos, cercados por capões ou matas de galeria formadas pela floresta ombrófila mista (mata de araucária) - apresentando, para alguns observadores, certa semelhança ao bioma do cerrado (MAACK, 1948).

A formação territorial dessa região e a consequente transformação da paisagem foram intensificadas a partir dos ciclos econômicos que ali se estabeleceram. Durante o século XVII, os campos limpos e os outros elementos do meio natural atraíram a atenção do bandeirantismo paulista uma vez que os Campos Gerais eram considerados propícios para a criação de gado. Assim, esses elementos foram determinantes para o estabelecimento das primeiras frentes de ocupação da região, com destaque para o tropeirismo.

Iniciado em 1731, o movimento do tropeirismo é considerado o principal vetor da ocupação desta região (PADIS, 2006), pois os campos naturais se tornaram um atrativo para a invernada dos animais de carga que se dirigiam do Rio Grande do Sul à Sorocaba, no estado de São Paulo. Despontado pela necessidade de abastecimento e transporte de animais às áreas de mineração em Minas Gerais, o tropeirismo foi um ciclo pulsante até meados do século XIX.

Ao longo da rota dos tropeiros eclodiram alguns núcleos de povoamento que se tornariam as cidades das mais antigas do estado como, por exemplo, Castro e Lapa. Além disso, a rota configurou uma rede urbana onde "cada cidade está separada da outra por uma distância que corresponde a um dia de viagem tropeiro" (PADIS 2006, p.57).

Sendo uma atividade dominada por um pequeno número de fazendeiros, a pecuária extensiva requisitava grandes extensões de terra para a criação do gado. Portanto, a estrutura agrária dos Campos Gerais começou a ser 
DIAS, B. B. ,FAJARDO, S.

\section{ARTICULAÇÕES ENTRE O ESTADO E O COOPERATIVISMO AGRÍCOLA: UM ESTUDO SOBRE AS COOPERATIVAS DE IMIGRANTES HOLANDESES NOS CAMPOS GERAIS DO PARANÁ}

instituída a partir do tropeirismo, se tornando a base do latifundiarismo nos Campos Gerais (ALBUQUERQUE, AUED, 2008). Exemplificando como essa situação foi moldada, Cunha (2003, p.40) atesta que

A presença do latifúndio pode ser explicada pelo fato da ocupação da região ter ocorrido no período em que a constituição de grandes fazendas dependia de uma concessão de terras (sesmarias), pelas autoridades nomeadas pela coroa. O que acontecia é que as terras eram primeiramente ocupadas por fazendas, concretizando a posse, e depois se requeria a regularização a partir da concessão.

Portanto, o tropeirismo acabou se convertendo na primeira atividade econômica capaz de sistematizar a ocupação e o povoamento dessa parcela do território paranaense.

Durante o século XIX, a região dos Campos Gerais vivenciou a expansão dos ciclos da erva-mate e da indústria madeireira (a partir da extração da Mata de Araucárias), fatores que deram solidez ao caráter extrativista da economia regional.

Entretanto, ganham destaque os projetos de imigração europeia estimulados nas últimas décadas do século XIX. Nesse período, muitas das políticas migratórias aplicadas no Brasil surgiram com o pretexto de ocupar os 'vazios demográficos' do território, principalmente, com imigrantes europeus (política de branqueamento da população ${ }^{4}$ ) para assegurar o desenvolvimento de atividades econômicas voltadas ao setor agrícola.

\footnotetext{
${ }^{4}$ No contexto pós-abolicionista, ganhou força a estratégia de "branqueamento da população" apoiada, principalmente, pelas elites nacionais. Costa e Ferreira (1999, p.145) afirmam que "não se tratava apenas de povoar terras, mas de povoálas com o tipo humano ideal aos olhos luso-brasileiros (...)", neste caso, alemães, italianos e outras etnias europeias que serviriam para substituir a mão de obra escrava recémabolida e ocupar áreas de escassez populacional no interior do país.
}

No estado do Paraná, particularmente, Costa e Ferreira (1999, p.145) apontam que

(...) o governo passava a olhar uma província recém-emancipada, vizinha da Argentina, e do recémcombatente inimigo, Paraguai. Tratava-se do Paraná. Local de clima ameno e povoamento insignificante, com fazendas de gado e sociedade nada influente junto à corte; parecia ser o local ideal para a realização dos planos "branqueadores" da burguesia. A província do Paraná passa a chamar para si, a atenção dos imigrantistas. As terras férteis e ainda pouco povoadas, cobertas pela mata virgem e contempladas pelo clima ameno do sul, parecia o cenário perfeito para a instalação do europeu.

Nesse contexto, a iniciativa de criar colônias de imigração europeia nos Campos Gerais se tornou uma tentativa de reprodução da estrutura camponesa à maneira da Europa. Assim, a partir das primeiras décadas do século $X X$ a região se tornou um ambiente propício para a criação de três importantes colônias de imigração holandesa. A seguir, aponta-se como esse processo se configurou. Procura-se destacar o estímulo concedido pelo Estado brasileiro e o respaldo do governo holandês.

\subsection{A criação das colônias e cooperativas de imigrantes holandeses nos Campos Gerais do Paraná}

Em 1909, após seis semanas de viagem pelo Atlântico, o primeiro navio com imigrantes holandeses atracou no porto de Paranaguá, trazendo indivíduos que se transformariam em importantes personagens da história e da geografia paranaense. Vindos em sua maioria das

\footnotetext{
5 No ano de 1853 a província do Paraná emancipa-se oficialmente da província de São Paulo (COSTA; FERREIRA, 1999).
} 


\section{ARTICULAÇÕES ENTRE O ESTADO E O COOPERATIVISMO AGRÍCOLA: UM ESTUDO SOBRE AS COOPERATIVAS DE IMIGRANTES HOLANDESES NOS CAMPOS GERAIS DO PARANÁ}

regiões de Drenthe e Overijssel, na porção nordeste da Holanda, os imigrantes foram atraídos à região por um contrato firmado entre o Estado brasileiro com a empresa Brazil Railway Company ${ }^{6}(B R C)$, responsável pela construção da Estrada de Ferro São Paulo-Rio Grande ${ }^{7}$, numa parceria que daria sustentação ao processo de imigração (GALLAS; GALLAS, 2002).

A primeira colônia holandesa da região foi criada no ano de 1911 quando, no atual município de Carambeí (antigo distrito de Castro), se fixaram os imigrantes holandeses vindos do distrito de Gonçalves Junior (município de Irati).

Na colônia de Carambeí, a constatação de que "os solos dos Campos Gerais do estado do Paraná são lixiviados, arenosos e ácidos, pobres em elementos nutritivos e matéria orgânica" (WAIBEL, 1979, apud CUNHA, 2011, p. 134), foi fator determinante para que os colonos orientassem suas atividades em torno da pecuária. Para dar suporte a essa atividade, em 1912, chegaram os primeiros gados da raça holandesa. Vindos diretamente da Holanda, esses animais foram fundamentais para dar início às atividades de pecuária leiteira, estabelecendo o norte para o desenvolvimento econômico da colônia.

No ano de 1925 a organização dos imigrantes em torno do cooperativismo resultou na criação da Sociedade Cooperativa Holandesa de Laticínios que, inicialmente, contava com apenas 07 associados. Dessa cooperativa se originou a marca Batavo ${ }^{8}$, fundada em 1928.

\footnotetext{
${ }^{6}$ Empresa fundada em 1906, em Maine EUA, pelo milionário Percival Farquhar, empresário estadunidense que possuía diversos projetos de infraestrutura em alguns países da América Latina. Em apenas seis anos, a BRC se tornou a maior empresa ferroviária privada do Brasil, controlando em dez anos de atividade cerca de $11.000 \mathrm{~km}$ dos $23.400 \mathrm{~km}$ existentes no país - equivalente a $47 \%$ da malha ferroviária. A empresa se manteve em atividade até 1917 (GALLAS; GALLAS, 2012, p.39).

7 A mesma ferrovia que, anos depois, se tornaria pretexto para a Guerra do Contestado (1912 - 1916).

8 Em 1928 os colonos de Carambeí instituíram a marca Batavo, registrada oficialmente em 1941, que acabou se tornando uma referência nacional em produtos de leite e derivados (Disponível em: http://www.batavo.com.br/conheca-a-nossa-historia/. Acesso em 20/07/2018)
}

Anos mais tarde, o projeto que viria a constituir a colônia de Castrolanda foi marcado por menos incertezas e mais assistência dos governos do Brasil $^{9}$ e da Holanda. No contexto do pós-guerra,

(...) começaram a surgir muitos programas de estímulo à emigração de países europeus. A Holanda, um dos países que mais sofreu com os bombardeios alemães, teve seu território praticamente devastado pela guerra. Diante disto, algumas organizações civis passaram a elaborar programas de emigração em cooperação com outros países, como no caso brasileiro (LOPES, 2015, p.24).

Uma vez consolidada a primeira colônia de imigração holandesa nos Campos Gerais do Paraná, a criação da segunda colônia, Castrolanda, foi concretizada no ano de 1951 durante o governo de Olívio Gaspar Dutra. Gallas e Gallas (2012) destacam que Castrolanda resultou de uma parceria firmada entre Brasil e Holanda através de uma cooperativa de imigração ${ }^{10}$. Desde o início do projeto, já estava prevista a criação de uma cooperativa agropecuária para dar suporte à organização trabalhista dos imigrantes. Assim, no ano de 1951 foi instituída a Cooperativa Castrolanda.

\footnotetext{
9 Houve uma forte contribuição dos governos federal e estadual na liberação de recursos. Nesse sentido, o executivo paranaense se dispôs a comprar os lotes de terra que seriam utilizados para abrigar a colônia. Já o governo federal, investiu cerca de 7.470 .000 de cruzeiros em projetos de financiamento a médio prazo. Sendo assim, o Estado brasileiro garantiu a sustentação necessária para que os lotes de terra começassem a ser repassados aos imigrantes holandeses (GALLAS; GALLAS, 2012).

10 Composta por diversos profissionais, esse grupo seria responsável pelo levantamento e avaliação de algumas áreas do território brasileiro que supostamente poderiam abrigar a nova colônia. Em 1951, o governo holandês auxiliou na criação de uma cooperativa de emigração, intitulada Cooperativa para Emigração em Grupo para o Brasil (CEGB). Suas ações seriam voltadas exclusivamente para organizar o processo migratório. A CEGB foi responsável pela distribuição dos lotes de terra, que variavam de 35 a 200 hectares/cada, além de definir sob quais condições os lotes seriam financiados (GALLAS; GALLAS, 2012).
} 


\section{ARTICULAÇÕES ENTRE O ESTADO E O COOPERATIVISMO AGRÍCOLA: UM ESTUDO SOBRE AS COOPERATIVAS DE IMIGRANTES HOLANDESES NOS CAMPOS GERAIS DO PARANÁ}

A presença dos imigrantes holandeses em Carambeí e Castrolanda acabou contribuindo de forma significativa para a formação da terceira colônia, no município de Arapoti. No início da década de 1960, a Holanda já apresentava sinais de recuperação dos efeitos negativos da Segunda Guerra Mundial. Por esse motivo, das 100 famílias holandesas que planejaram emigrar, somente 50 acabaram se engajando no projeto. Em 1960, com a colônia já consolidada, surgiu a cooperativa Capal (GALLAS; GALLAS, 2012).

A vida em terras brasileiras impôs certas dificuldades de adaptação aos colonos, os quais tiveram que superar algumas adversidades de natureza econômica, sociocultural e geoclimática impostas pelo processo migratório. Para enfrentar esses desafios, os imigrantes holandeses passaram a se unir em torno de um trabalho em equipe, compartilhando valores religiosos e de sociabilidade.

No início de suas trajetórias, o sustento econômico dos cooperados se limitava a pequenas porções de terra e um número reduzido de animais (vacas leiteiras). A partir dessa limitação, passaram a buscar alternativas para a obtenção de maior sucesso em suas atividades econômicas. A solução encontrada foi aplicar as técnicas da pecuária leiteira holandesa à produção, país que possui um histórico de inovações e altos índices de produtividade neste setor.

A partir de então, os imigrantes holandeses começaram a desenvolver uma produção leiteira altamente tecnificada, trilhando caminhos mais promissores em território paranaense. Os elementos do clima e o relevo dos Campos Gerais foram decisivos para o desenvolvimento dessa atividade. Soma-se a isso, a herança cultural e o know-how trazido pelos holandeses no ramo leiteiro. Organiza-se, então, a conjuntura que, anos depois, tornaria a região num polo irradiador de sofisticadas técnicas de produção leiteira para o país.

Partindo desse princípio, os imigrantes conseguiram demonstrar alguns aspectos da ruralidade holandesa, seja através das expressões, dos significados ou manifestações sociais reproduzidas no espaço rural paranaense.
Como reflexo da condição social, territorial e cultural pela qual foram submetidos, deram um novo significado às características dessa ruralidade (LAUBSTEIN, 2011).

Como alternativa para superar coletivamente as dificuldades econômicas, esses imigrantes integraram suas respectivas produções leiteiras em torno do ideal cooperativista. Assim, poderiam industrializar e comercializar o leite produzido nas propriedades cooperadas.

Essa iniciativa se consolida em 1954, quando os cooperados da Batavo e da Castrolanda se empenharam para criar a Cooperativa Central de Laticínios do Paraná Ltda (CCLPL). Alguns anos depois, os cooperados da Capal também passariam a integrar esse arranjo produtivo.

A integração produtiva foi fundamental para o fortalecimento das cooperativas. $\mathrm{Na}$ década de 1950, já se observava um aumento do nível técnico da produção, retratado pela intermediação promovida por agrônomos vindos diretamente da Holanda que prestavam assistência técnica às cooperativas da CCLPL. Além disso, a importação do gado Puro de Origem da Holanda daria início à especialização da pecuária leiteira, influenciando diretamente nos processos de melhoramento genético do rebanho e no aumento da produtividade. Ainda na década 1950, a técnica da inseminação artificial já era largamente utilizada pelos imigrantes holandeses (FUNDAÇÃO ABC, 2015).

A partir desse momento, a busca por aperfeiçoamento técnico se tornou uma tradição entre os colonos. Em cada cooperativa ligada à CCLPL, foi criado um Departamento de Assistência Técnica (DAT), pasta responsável pelo fomento de pesquisas científicas nas áreas de nutrição animal, melhoramento genético do rebanho e técnicas de manejo do solo (FUNDAÇÃO ABC, 2015). As atividades desenvolvidas pelos DAT's eram subsidiadas diretamente pela contribuição de cada membro cooperado e retratavam os anseios de cada cooperativa na busca por melhor desempenho produtivo. 


\section{ARTICULAÇÕES ENTRE O ESTADO E O COOPERATIVISMO AGRÍCOLA: UM ESTUDO SOBRE AS COOPERATIVAS DE IMIGRANTES HOLANDESES NOS CAMPOS GERAIS DO PARANÁ}

Entretanto, o panorama do setor agropecuário brasileiro começaria a mudar a partir de 1960 com a inserção das lavouras de soja, o novo 'ouro verde' do agronegócio. Acompanhando de perto as tendências econômicas desse setor, o Estado brasileiro direcionou sua atenção para que o cooperativismo também pudesse se alinhar ao novo modelo de produção agrícola que começava a despontar. Na próxima sessão, será discutido como as cooperativas de imigrantes holandeses se comportaram diante desse cenário.

\subsection{A modernização da agricultura nos Campos} Gerais do Paraná e o papel das cooperativas de imigrantes holandeses

Desde o início de suas trajetórias, as cooperativas de imigrantes holandeses contaram com fortes incentivos do Estado, seja pela custódia de políticas públicas, seja por linhas de crédito e financiamento oferecidas por bancos públicos, sendo munidas pela intervenção estatal para sustentar suas atividades ${ }^{11}$. Em contrapartida, auxiliaram o Estado nos objetivos subjacentes às suas políticas agrícolas.

Desta forma, as cooperativas do grupo CCLPL (Batavo, Castrolanda e Capal) tiveram papel fundamental na introdução e no desenvolvimento de sistemas intensivos de produção agrícola na região dos Campos Gerais do Paraná. Foram agentes que estiveram à frente do processo de reprodução das monoculturas mecanizadas voltadas ao mercado externo, contribuindo para a entrada do modelo de agricultura científica globalizada na região.

O florescimento da soja enquanto commodity agrícola alterou significativamente a dinâmica de atuação dessas cooperativas. Para o Estado, estimulá-las à adesão das lavouras de soja era uma prerrogativa para a eficácia de suas políticas agrícolas.

Para as cooperativas do grupo CCLPL, a inserção da produção de commodities ganharia

\footnotetext{
11 Desde a década de 1940 o crédito agrícola já era ofertado aos cooperados da Batavo, sendo utilizado como mecanismo de financiamento da produção. A compra de tratores pelos cooperados, por exemplo, era intermediada pelo Banco do Brasil desde 1953, estimulando os cooperados à modernização da produção (GALLAS; GALLAS, 2012).
}

ainda mais estímulo, uma vez que o aumento das cabeças de gado suscitaria maior produção das pastagens de milho, soja e trigo para a alimentação do rebanho.

Porém, ao se intensificar o nível de mecanização, os cooperados começaram a constatar alguns sinais de desgaste e esgotamento das propriedades do solo da região. Havia, portanto, um obstáculo físico a superar.

Para desenvolver uma agricultura intensiva e de larga escala nos Campos Gerais, era preciso contornar os problemas de um solo arenoso e facilmente suscetível à erosão. Em entrevista ao periódico Paraná Cooperativo ${ }^{12}$, Franke Dijkstra, um dos pioneiros da colônia de Carambeí, descreve que

(...) na segunda metade da década de 1960, tiveram início os plantios de soja e trigo nos Campos Gerais. E eu comecei também a cultivá-los. Nos primeiros anos foi tudo muito promissor, mas logo sobreveio a erosão. As terras da região eram frágeis e, com duas culturas ao ano, a degradação chegou rápido.

Condicionadas por esse cenário desfavorável, as cooperativas, por intermédio das ações dos DAT's, começaram a estabelecer convênios com empresas e profissionais do setor agrícola, visando a uma solução técnica capaz de sustentar a agricultura de larga escala no solo dos Campos Gerais. Diante da conjuntura do mercado agrícola daquele período, onde a soja estava se tornando mais rentável que o leite, era necessário buscar soluções.

Com as intervenções dos DAT's, as cooperativas passaram a contar com o respaldo técnico de um experiente grupo de agrônomos, incluindo, entre eles, o holandês Hans Peeten, especialista na técnica do plantio direto ${ }^{13}$. A

\footnotetext{
${ }^{12}$ Ano 11, número 129, nov/2015, p.06.

13 Técnica agrícola que começou a ser desenvolvida na Inglaterra (1950), EUA e Alemanha (1960). Procura economizar energia no trabalho de aração, praticando-se o plantio das novas sementes diretamente na palha da colheita anterior, evitando o processo de revolvimento da terra. 0
} 


\section{ARTICULAÇÕES ENTRE O ESTADO E O COOPERATIVISMO AGRÍCOLA: UM ESTUDO SOBRE AS COOPERATIVAS DE IMIGRANTES HOLANDESES NOS CAMPOS GERAIS DO PARANÁ}

aplicação desse método no solo dos Campos Gerais acabou se tornando um grande sucesso, estimulando ainda mais o desenvolvimento de pesquisas e aperfeiçoamento técnico pelas cooperativas.

O emprego do plantio direto garantiu autonomia, solidez e sustentabilidade econômica ao modelo de agricultura que começava a ser promovido pelas cooperativas de imigrantes holandeses. Devido ao seu sucesso, a técnica se disseminou pela agricultura dos Campos Gerais, possibilitando o cultivo em grandes extensões de terra. A partir desse momento, as cooperativas estariam preparadas para se integrar à lógica da agricultura moderna, baseada na expansão das lavouras mecanizadas.

Contudo, a tradição de investimento em pesquisa agropecuária dos imigrantes e descendentes teve seu ápice em 1984, quando foi fundada a Fundação ABC. Sediada no município de Castro, sua gênese está relacionada à unificação dos respectivos DAT's das cooperativas. A instituição de pesquisa privada foi a primeira empresa do gênero no país a desenvolver sistemas de tecnologia em plantio direto. A Fundação $A B C$ passou a funcionar, basicamente, como uma extensão das cooperativas, auxiliando os membros da Batavo, Castrolanda e Capal a obterem maior aperfeiçoamento técnico.

Com todo o respaldo técnico prestado pela Fundação $A B C$, as cooperativas conseguiram aumentar significativamente os níveis de produtividade ${ }^{14}$, tanto na agricultura quando na pecuária leiteira. A partir dessas iniciativas, tiveram solidez para sustentar o processo de

emprego dessa técnica contribui para evitar a erosão dos solos, economizar água e mão de obra, preservar a matéria orgânica no solo e, consequentemente, aumentar o lucro e a produtividade agrícola. (GALLAS; GALLAS, 2012).

\footnotetext{
${ }^{14}$ Dados encontrados no site da EMBRAPA revelam que a média de produtividade nacional para soja e milho correspondem, respectivamente, a $3.011 \mathrm{~kg} / \mathrm{ha}$ e $5.400 \mathrm{~kg} / \mathrm{ha}$. A título de exemplificação, durante as safras de 2000 a 2015, os cooperados da Castrolanda obtiveram média de $3.153 \mathrm{~kg} / \mathrm{ha}$ para a soja e $9.152 \mathrm{~kg} / \mathrm{ha}$ para o milho, comprovando a superioridade da produção dos cooperados em relação à média nacional.
}

verticalização ${ }^{15}$ e o respectivo encaixe ao modelo do Complexo Agroindustrial brasileiro.

Dessa forma, podemos afirmar que a verticalização das cooperativas do grupo CCLPL se tornou viável quando assumiram o modelo de agricultura comercial voltado à grande produção de commodities, produção que se embasa e depende de um pacote de recursos financeiros, técnicos, científicos e informacionais. Essas características comprovaram o alinhamento das cooperativas aos ditames do mercado agrícola e do grande capital global, o que contribuiu para dinamizar a agricultura dos Campos Gerais e, consequentemente, fragmentar a paisagem natural da região.

3.3 Os impactos da conjuntura neoliberal para as cooperativas de imigrantes holandeses: fusões e aquisições, reestruturação produtiva e as novas estratégias de acumulação

A verticalização produtiva baseada na inserção das commodities se tornou pujante até meados da década de 1980, período em que as cooperativas se depararam com uma estagnação. A conjuntura da economia brasileira no final dos anos 1980 não deixou dúvidas sobre o porquê do desmantelamento de diversos setores da indústria nacional.

O Estado brasileiro, enfrentando uma das maiores inflações do mundo naquele momento teve que adotar medidas ortodoxas no campo econômico, visando reequilibrar a economia nacional. Diante desse cenário, diversos setores se depararam com dificuldades financeiras ocasionadas pela queda de empréstimos, investimentos, financiamentos e outros subsídios antes oferecidos com o jubilo do Estado. Assim, o Estado não teve outra saída senão o afrouxamento das políticas creditícias voltadas ao setor agrícola, pois

\footnotetext{
15 Segundo Fajardo (2008), a verticalização de uma cooperativa agropecuária está associada ao processo de agroindustrialização, ou seja, ao investimento no processamento industrial. Após esse processo, muitas cooperativas agropecuárias obtiveram um salto de produção e arrecadação, passando, inclusive, a se denominar cooperativas agroindustriais.
} 


\section{ARTICULAÇÕES ENTRE O ESTADO E O COOPERATIVISMO AGRÍCOLA: UM ESTUDO SOBRE AS COOPERATIVAS DE IMIGRANTES HOLANDESES NOS CAMPOS GERAIS DO PARANÁ}

reconhecia o início do fim de um modelo agrícola baseado no crédito rural abundante e barato, que a partir daquele momento passava a ser reestruturado, de forma gradativa, mas constante. No entanto, só em 1980 o processo consolidou-se com as profundas modificações efetuadas na Política de Crédito Rural em função do agravamento da crise brasileira. Essas modificações foram basicamente o aumento dos juros e a diminuição do volume de créditos (CUNHA, 1986, p.115).

Essa medida impactou diretamente a dinâmica de atuação das agroindústrias e demais instituições do setor agrícola. No caso das cooperativas agropecuárias, pouco se viu em termos de crescimento durante os anos 1980, o que levou Gonçalves (2012) a rotular o período como a 'década perdida do cooperativismo'. De maneira geral, essa década ficou marcada "pelo abandono do padrão protecionista que o Estado exercia sobre essas instituições" (GONÇALVES, 2012, p.32).

Nesse momento, as medidas do ajuste macroeconômico da década de 1990 e a inserção da política neoliberal abriram uma lacuna para a ação do capital internacional sobre as cooperativas do grupo CCLPL, pois "a Batavo há tempos procurava um parceiro que a tirasse da dificuldade financeira". Nesse período, a Batavo enfrentava o mesmo problema de endividamento da maioria das cooperativas do país, com dívida estimada, em 1997, em torno de $\mathrm{R} \$ 70$ milhões $^{16}$.

Assim, o neoliberalismo se deflagra sobre as cooperativas do grupo CCLPL. Em 1997, a CCLPL decidiu vender $51 \%$ de seus ativos à multinacional italiana Parmalat $^{17}$ Brasil S.A

\footnotetext{
${ }^{16}$ Segundo reportagem realizada pelo jornal Folha de São Paulo de 18/12/1997. http://www1.folha.uol.com.br/fsp/dinheiro/fi181232.htm Acesso em 06/04/2016.

17 Durante as décadas de 1980 e 1990 a multinacional Parmalat vivenciou um período de enorme crescimento no mercado brasileiro, chegando a obter $12 \%$ do setor de laticínios. Em contrapartida, na década seguinte, a empresa
}

Indústria de Alimentos, resultando na criação da Indústria de Alimentos Batávia S.A.

Anos mais tarde, problemas de gestão e endividamento fizeram com que a Parmalat enfrentasse um rápido declínio no mercado varejista brasileiro. Essas circunstâncias abriram caminho para que suas ações e operações fossem adquiridas pela Perdigão S.A no ano 2000, marca que integra o conglomerado agroalimentar BRFoods $^{18}$.

Mediante a dinâmica de fusões e aquisições que caracteriza o período neoliberal, o controle acionário da marca Batavo passou por diversas mudanças. Em 2014 a multinacional francesa Lactalis adquiriu as operações do setor de laticínios da gigante BRFoods ${ }^{19}$, tornando-se a atual representante da Batávia S.A no Brasil.

Esse complexo processo de venda e troca acionária da marca Batavo impulsionou os antigos cooperados de Carambeí a buscar um resgate ao modelo cooperativista que haviam trazido no início da colônia. Com o pretexto de desvincular suas atividades de pecuária leiteira da marca que havia sido entregue aos domínios da do capital internacional, decidiram criar uma nova cooperativa agroindustrial com atuação no segmento de leite e derivados.

Nesse sentido, em 2011 foi criada a cooperativa Frísia, cujo nome remete a região geográfica da Holanda de onde vieram os primeiros imigrantes da colônia de Carambeí. Desde então, a cooperativa Frísia passou a atuar nos mesmos segmentos que a antiga Batavo, sendo representada no setor varejista de leite e derivados pela marca "Colônia Holandesa”.

entrou em um rápido processo de endividamento crônico, resultando na venda de suas ações para o grupo Perdigão. https://www.gazetadopovo.com.br/agronegocio/mercado/pa rmalat-perdigao-brf-e-lactalis-em-20-anos-marca-paranaensepassou-de-mao-em-mao-f1khzo0v96ak4rdrakeyrt0af. Acesso em 20/07/2018.

18 Fundada em 2009, o conglomerado BRFoods resultou da fusão das gigantes do ramo alimentar brasileiro, Sadia e Perdigão. Ao adquirir a Parmalat, em 2007, o grupo passou a comercializar os produtos lácteos da marca Batavo.

${ }^{19}$ https://www.gazetadopovo.com.br/agronegocio/mercado/ parmalat-perdigao-brf-e-lactalis-em-20-anos-marcaparanaense-passou-de-mao-em-mao-

f1khzo0v96ak4rdrakeyrt0af. Acesso em 20/07/2018. 
DIAS, B. B. ,FAJARDO, S.

\section{ARTICULAÇÕES ENTRE O ESTADO E O COOPERATIVISMO AGRÍCOLA: UM ESTUDO SOBRE AS COOPERATIVAS DE IMIGRANTES HOLANDESES NOS CAMPOS GERAIS DO PARANÁ}

Após esse parêntese sobre os rumos da Batavo, cabe destacar que durante grande parte da década de 1990 o principal mecanismo de financiamento do Estado para o setor cooperativista se deu mediante a contração de dívidas, contrapondo o autofinanciamento de outrora. Este fator acabou limitando o crescimento de diversas cooperativas, expondoas de forma significativa às vulnerabilidades do mercado (GONÇALVES, 2012). Foi dentro desse contexto que as cooperativas do grupo CCLPL passaram por um período de estagnação e respectivo endividamento durante a década de 1990.

Mas o Estado logo criou uma alternativa. Em 1998, com reequilíbrio inflacionário e a resposta positiva do mercado ao Plano Real, foi criado o Programa de Revitalização de Cooperativas de Produção Agropecuária (RECOOP), sendo incluídas as cooperativas Batavo, Castrolanda e Capal.

O RECOOP foi um programa destinado à recuperação financeira das cooperativas agroindustriais de grande porte, as quais poderiam transferir parte de suas dívidas à união. Além da atuação do RECOOP ${ }^{20}$, muitos produtores cooperados que se encontravam endividados foram atendidos pelo Programa Especial de Sanamento de Ativos ${ }^{21}$ (PESA), outro programa responsável pelo refinanciamento de dívidas.

Através dessas políticas de reequilíbrio orçamentário e renegociação de dívidas como o RECOOP, as cooperativas do grupo CCLPL conseguiram adentrar novamente num cenário promissor de crescimento. Segundo Padilha (2014, p.68),

o RECOOP foi criado para corrigir as distorções causadas pelas políticas

\footnotetext{
${ }^{20}$ Formulado em 1995 e instaurado a partir da Medida Provisória no $1.781 / 98$, o programa transferiu o risco das dívidas das cooperativas para a União, exonerando tanto os agricultores quanto as cooperativas dos embargos financeiros provenientes do endividamento. Foram, aproximadamente, 2,5 bilhões de reais investidos no programa.

${ }^{21}$ Programa Especial de Sanamento de Ativos, instituído por meio da Resolução do Banco Central do Brasil (BACEN) no 2.471 , de 26 de fevereiro de 1998, o programa foi responsável por refinanciar e sanar dívidas de valores maiores que $R \$ 200$ mil.
}

econômicas do governo federal que nos anos de 1980 e início da década seguinte fizeram com que as instituições financeiras deixassem praticamente a responsabilidade de financiar o produtor rural ao sistema cooperativista, o que levou muitas cooperativas a enfrentar problemas de caixa.

No término de sua execução o programa RECOOP contemplou 322 projetos de refinanciamento às cooperativas agropecuárias do país, sendo destinado um montante de $R \$ 3,2$ bilhões arcados, em sua maioria, pelo Tesouro Nacional. Padilha (2014, p.74) destaca que o "RECOOP foi uma política que atuou num curto período de tempo e teve sua abrangência limitada a poucos estados, concentrando recursos e com vários problemas burocráticos". Mas, apesar desses empecilhos, o programa foi fundamental para a estabilização financeira e retomada dos investimentos das cooperativas contempladas.

No caso das cooperativas agropecuárias da região Sul, o Banco Regional de Desenvolvimento do Extremo Sul (BRDE) ${ }^{22}$ foi o grande articulador das linhas de financiamento do RECOOP. O banco foi responsável por disponibilizar recursos com juros baixos e de longo prazo, tanto para o refinanciamento de dívidas, como para a realização de novos investimentos (PADILHA, 2014).

$O$ apoio financeiro do BRDE às cooperativas do grupo CCLPL foi fundamental para suprir as necessidades de investimentos produtivos, o que até os anos 1990 era voltado para sanar dívidas (CAZAROTTO; PEREITA, 2012. p.187). O estudo de Cazarotto e Pereira (2012) identificou que as cooperativas contempladas pelos investimentos do BRDE "possuem hoje patrimônios elevados e desempenham papel estratégico para o desenvolvimento econômico e social das regiões onde estão inseridas" (p.189).

\footnotetext{
22 Entre 2000 e 2003 houve um incremento no volume de negócios realizados pelo BRDE. Em 2000, por exemplo, o BRDE disponibilizou às cooperativas cerca de R\$ 142 milhões, sendo que $89,3 \%$ desse valor era referente ao RECOOP (PADILHA, 2014).
} 


\section{ARTICULAÇÕES ENTRE O ESTADO E O COOPERATIVISMO AGRÍCOLA: UM ESTUDO SOBRE AS COOPERATIVAS DE IMIGRANTES HOLANDESES NOS CAMPOS GERAIS DO PARANÁ}

Assim, ao aderirem ao RECOOP ${ }^{23}$ as cooperativas Batavo/Frísia, Castrolanda e Capal ganharam novo fôlego para reerguer seus respectivos quadros financeiros e ampliar suas estruturas produtivas. A ação do BRDE, como banco público, teve a função de fomentar o desenvolvimento econômico e social de médio e longo prazo das três cooperativistas.

A partir da década de 2000, o ciclo de expansão das commodities responsável por alavancar os investimentos do Estado no setor agrícola fez com que novas políticas de financiamento fossem colocadas em prática. Com elas, voltaram as políticas de créditos com juros baixos e de longo prazo que visavam financiar a produção agropecuária das cooperativas e investir na expansão de suas estruturas produtivas.

Em 2002 as cooperativas Frísia e Castrolanda foram assistidas pelo Programa de Desenvolvimento Cooperativo para Agregação de Valor à Produção Agropecuária ${ }^{24}$ (PRODECOOP). Acompanhando as tendências do cooperativismo agropecuário nacional, o PRODECOOP permitiu a essas cooperativas novas estratégias de atuação mediante ao beneficiamento de novas cadeias produtivas. Guiadas novamente pelo Estado, via BRDE, foram contempladas com vastas linhas de financiamento fornecidas pelo banco estatal.

Com os investimentos provenientes do PRODECOOP, as cooperativas Frísia e Castrolanda intensificaram a verticalização de outras cadeias produtivas, o que antes se limitava às commodities. Assim, foram capazes de beneficiar a produção de leite e derivados, além de produtos agrícolas, como feijão, trigo e batata,

\footnotetext{
${ }^{23}$ Dos documentos analisados neste trabalho, o Relatório Anual da Castrolanda de 2009 foi o último a vincular uma parcela do endividamento da cooperativa ao programa RECOOP. Neste documento consta que em 2008 o RECOOP consumia cerca de 1.455 milhão do montante de endividamento da cooperativa (Relatório Anual Castrolanda, 2009)

${ }^{24}$ Decretado pelo BACEN vide Resolução $n^{\circ} 2.987$, de 03 de julho de 2002 e com respaldo do BNDES. Propiciou a modernização dos sistemas produtivos das cooperativas, para que pudessem realizar o beneficiamento da produção, agregar valor aos seus produtos e lançá-los ao varejo.
}

contribuindo diretamente para o aumento do faturamento.

Alimentadas pelo PRODECOOP, elas conduziram novas estratégias de mercado quando guiaram suas operações ao segmento do varejo. Como resultado, a partir de meados da década de 2000, as prateleiras dos centros de varejo passaram a receber diversos produtos das marcas Castrolanda e Colônia Holandesa, representadas, respectivamente pelas cooperativas Castrolanda e Frísia.

O lançamento de produtos no varejo tornou o faturamento das cooperativas mais dinâmico, pois ampliou suas variáveis de arrecadação. Produtos derivados do leite como creme de leite, leite condensado e bebida achocolatada; batata frita, feijão, além de derivados de carne, se tornaram elementos chave para estreitar, simbolicamente, a relação das cooperativas com o consumidor final. Dessa forma, a partir do período pós PRODECOOP, percebe-se um verdadeiro boom de faturamento das cooperativas, como demonstrado nas linhas dos gráficos 1,2 e $3^{25}$.

Cabe destacar que entre as três cooperativas, a Capal apresenta a arrecadação mais baixa devida uma menor flexibilidade de atuação no mercado, limitando-se à produção de commodities, leite e derivados e, mais recentemente, ao café, por produtores cooperados localizados na região do vale do Paranapanema. Já a cooperativa Frísia e a Castrolanda possuem maiores montantes de arrecadação, o que se justifica pelo maior dinamismo da produção e pela capilaridade de seus produtos no varejo.

\footnotetext{
${ }^{25}$ Percebe-se que as cooperativas têm alcançado percentuais de faturamento compatíveis com o perfil de grandes agroindústrias. No caso da Castrolanda, a arrecadação ultrapassou a marca de 2bilhões no ano de 2015.
} 
DIAS, B. B. ,FAJARDO, S.

\section{ARTICULAÇÕES ENTRE O ESTADO E O COOPERATIVISMO AGRÍCOLA: UM ESTUDO SOBRE AS COOPERATIVAS DE IMIGRANTES HOLANDESES NOS CAMPOS GERAIS DO PARANÁ}

Gráfico 1 - Faturamento bruto da Cooperativa Batavo/Frísia (1995 a 2015)

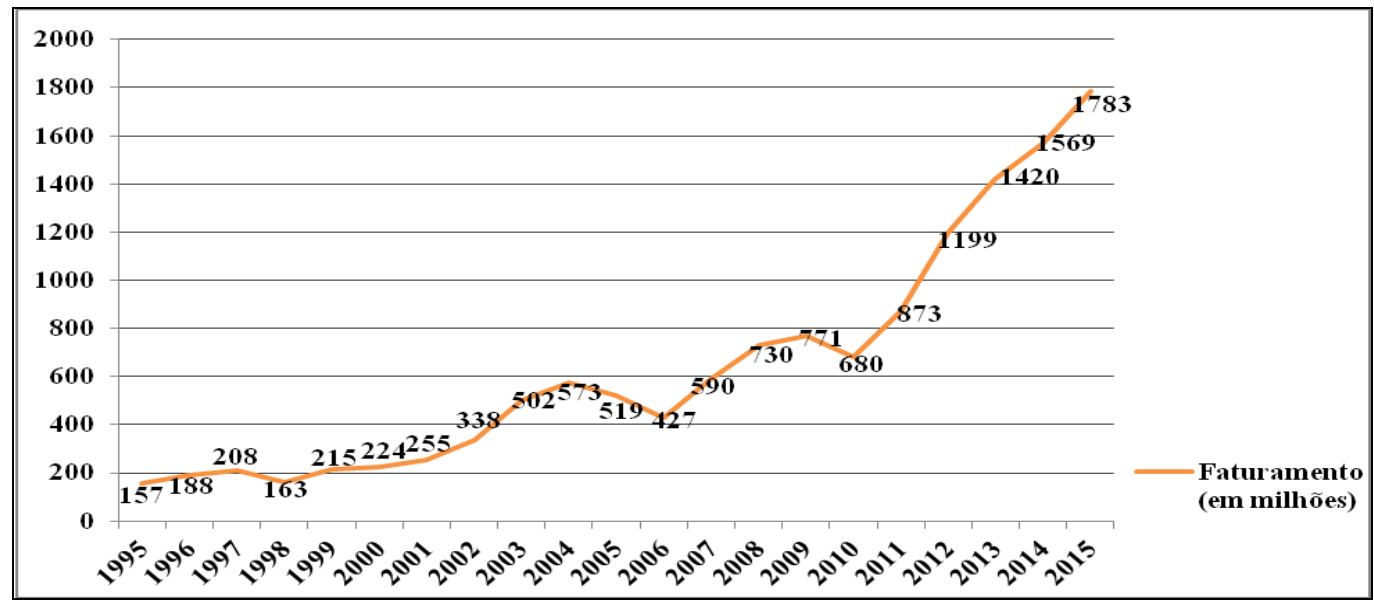

Fonte: Relatórios Anuais da Cooperativa Frísia.

Gráfico 2: Faturamento Bruto da Cooperativa Castrolanda (2000 a 2015)

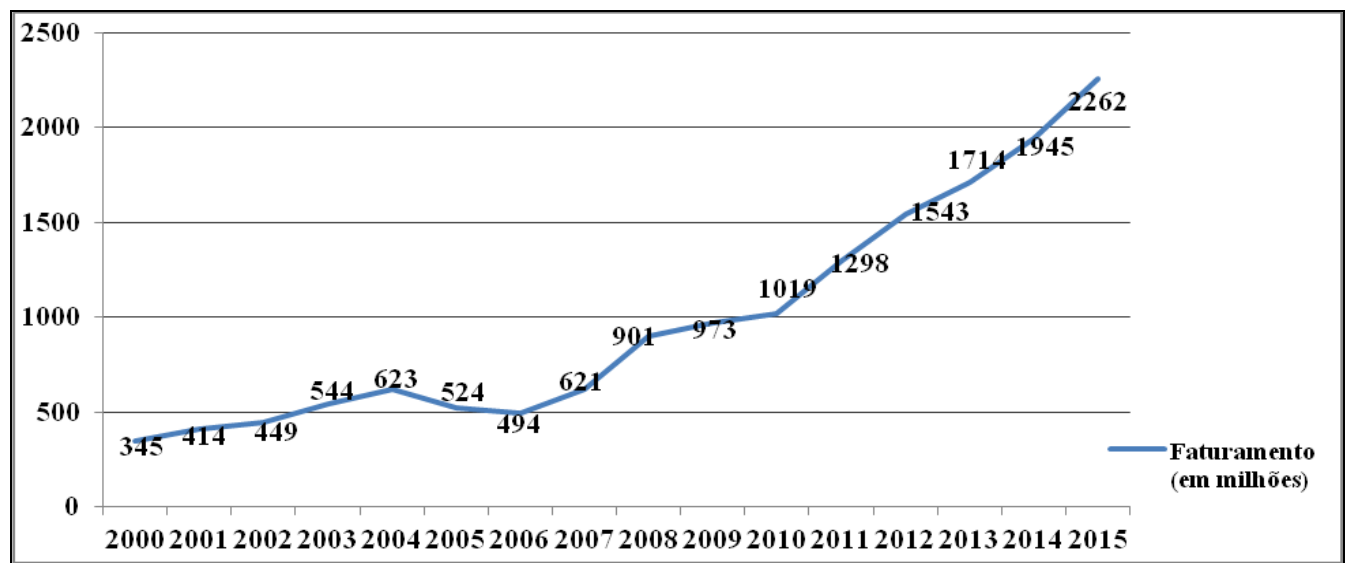

Fonte: Relatórios Anuais da Cooperativa Castrolanda.

Gráfico 3: Faturamento bruto da Cooperativa Capal (2002 a 2015)

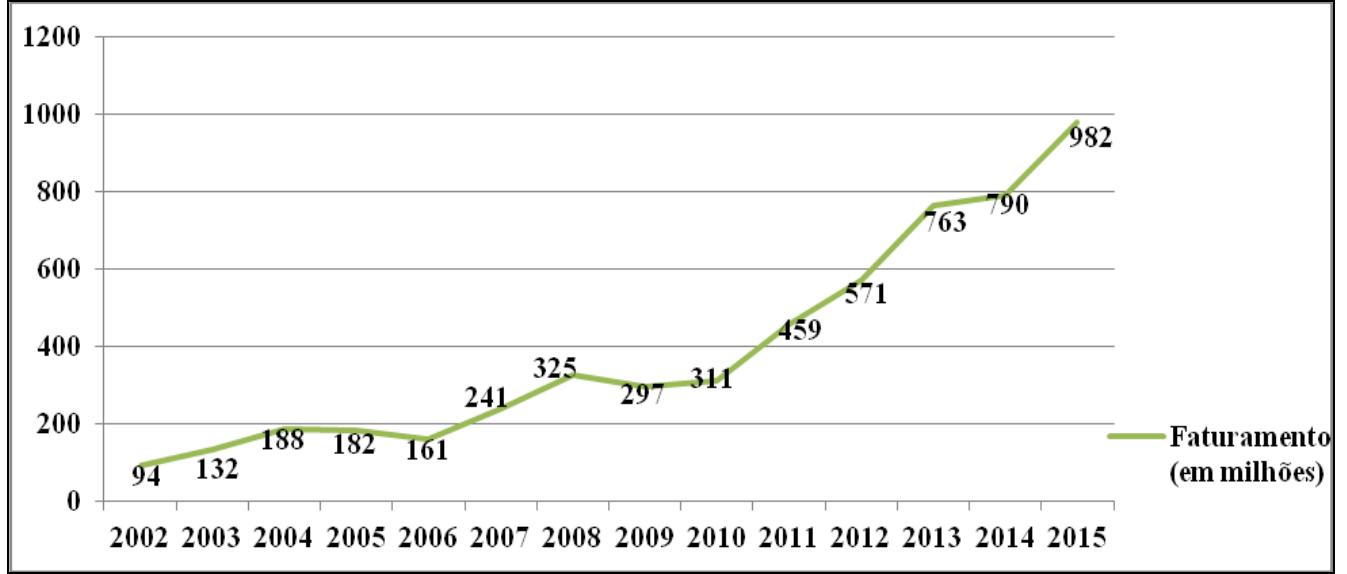

Fonte: Relatórios Anuais da Cooperativa Capal.

Entretanto, a partir da década de 2010, a grande aposta de mercado das três cooperativas voltou a ser o beneficiamento de leite. As Unidades de Beneficiamento de Leite (UBL's) instaladas em Carambeí/PR (Frísia), Castro/PR,
Itapetininga/SP e Macuco/RJ (Castrolanda), atuam num sistema integrado que recebe o leite dos cooperados mais próximos de cada uma dessas unidades. Além disso, o diferencial técnico e o manejo empregado pelos cooperados na 


\section{ARTICULAÇÕES ENTRE O ESTADO E O COOPERATIVISMO AGRÍCOLA: UM ESTUDO SOBRE AS COOPERATIVAS DE IMIGRANTES HOLANDESES NOS CAMPOS GERAIS DO PARANÁ}

produção leiteira têm contribuído para elevar o nível de qualidade do leite.

Como reflexo da industrialização de diversas cadeias produtivas, as cooperativas também passaram a se expandir horizontalmente no espaço. Isso se verifica pelo crescente número de unidades produtivas das cooperativas, espalhadas, principalmente, pelos territórios do Paraná e São Paulo (mapa 1 e mapa 2). A maioria dessas unidades foi criada a partir da década de 2000.

A Cooperativa Frísia possui um total de 22 unidades distribuídas, principalmente, pelo território dos Campos Gerais do Paraná. Sua estratégia de atuação horizontal está associada ao fornecimento de insumos, fertilizantes, sementes e produtos agropecuários nos municípios onde possui grande concentração de cooperados. O grande diferencial da Frísia com relação às outras, se encontra na produção e no beneficiamento do trigo. A cooperativa lançou uma marca de farinha de trigo específica para suas operações no varejo.
Além disso, essa cooperativa tem alçado estratégias de expansão para a região CentroOeste, visto pela Unidade de Armazenamento e Secagem no município de Paraíso do Tocantins/TO. A criação dessa unidade, no ano de 2015, resultou da estratégia de acompanhar as demandas de seus cooperados que estão ampliando suas operações agrícolas em áreas onde a fronteira agrícola possui potencial de expansão, como é o caso do Centro-Oeste brasileiro.

Dentre as três cooperativas de imigrantes holandeses, a Castrolanda se apresenta como a mais dinâmica em termos de ação territorial. Seu diferencial de atuação se encontra na maior capilarização das unidades de armazenamento e beneficiamento, promovendo uma forte industrialização da produção agropecuária. Essa característica vem permitindoIhe inserir uma série de produtos com maior valor agregado no mercado. 


\section{ESTADO DO PARANÁ}

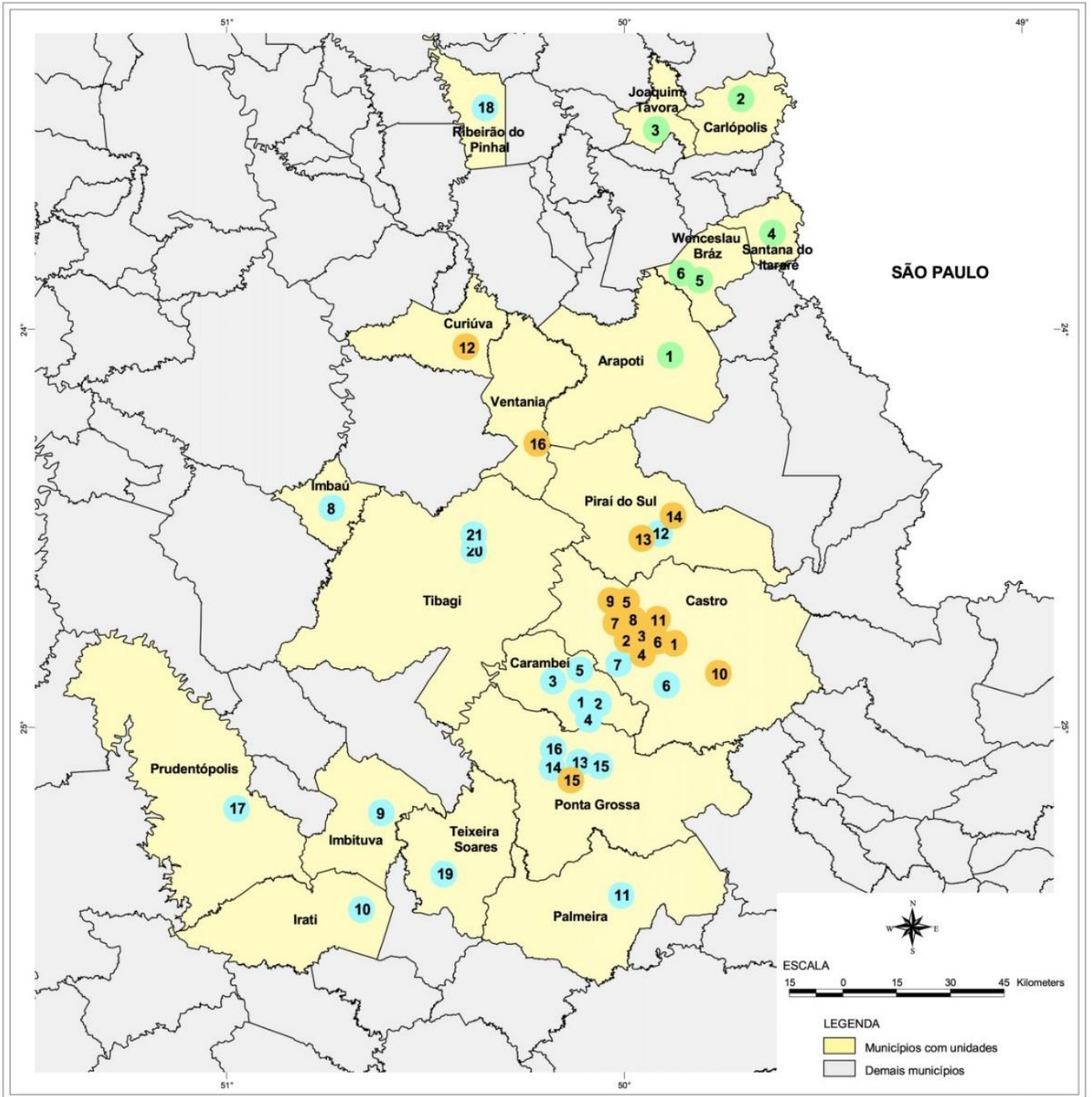

Mapa 1 - Unidades das Cooperativas Castrolanda, Capal e Frísia no Estado do Paraná em 2016

\begin{tabular}{|c|c|}
\hline Castrolanda Cooperativa Agroindustrial & Capal Cooperativa Agroindustrial \\
\hline \multirow{4}{*}{  } & $\begin{array}{l}\text { Arapoti } \\
\text { 1- Matriz }\end{array}$ \\
\hline & $\begin{array}{l}\text { Carlópolis } \\
2 \text { 2-Unidade Carlópolis }\end{array}$ \\
\hline & $\begin{array}{l}\text { Joaquim Távora } \\
\text { 3- Unidade Joaquim Távora }\end{array}$ \\
\hline & $\begin{array}{l}\text { Santana do Itararé } \\
\text { 4. Unidade Santana do Itararé }\end{array}$ \\
\hline $\begin{array}{l}\text { Curiúva } \\
\text { 12- Ammazém de Secagem }\end{array}$ & $\begin{array}{l}\text { Wenceslau Bráz } \\
\text { 5- Loja Agropecuária } \\
\text { 6- Unidade Wenceslau Brá }\end{array}$ \\
\hline $\begin{array}{l}\text { Pirai do Sul } \\
\text { 13- Amazém de Secagem } \\
\text { 14- Unidade de Beneficiamento de Gräos e Fábrica de Raçóes }\end{array}$ & \\
\hline $\begin{array}{l}\text { Ponta Grossa } \\
\text { 15-Amazém de Secagem }\end{array}$ & \\
\hline $\begin{array}{l}\text { Ventania } \\
\text { 16- Amazóm de Secagem e Beneficiamento de Sementes }\end{array}$ & \\
\hline
\end{tabular}

Fonte: (DIAS, 2016).






\section{ARTICULAÇÕES ENTRE O ESTADO E O COOPERATIVISMO AGRÍCOLA: UM ESTUDO SOBRE AS COOPERATIVAS DE IMIGRANTES HOLANDESES NOS CAMPOS GERAIS DO PARANÁ}

\section{ESTADO DE SÃO PAULO}

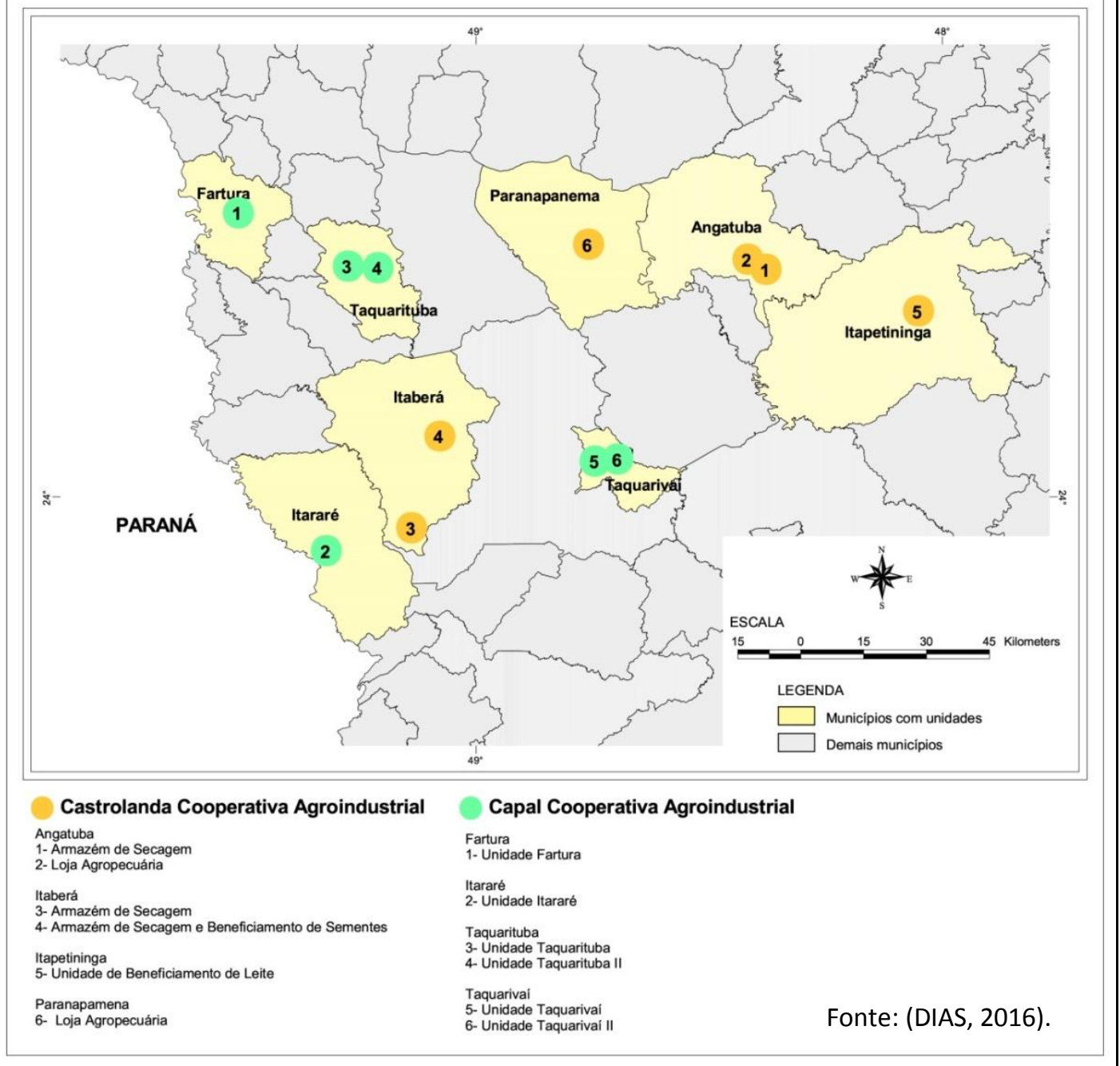

Mapa 2: Unidades da Castrolanda e Capal no Estado de São Paulo em 2016

A Castrolanda possui 23 unidades distribuídas em municípios dos Campos Gerais do Paraná e na porção sudeste do estado de São Paulo para onde, recentemente, tem lançado suas principais estratégias de expansão. Além disso, possui uma unidade produtiva no estado do Rio de Janeiro, adquirida no ano de 2015, como parte de uma nova estratégia de expansão no mercado varejista da região Sudeste.

A cooperativa Capal se apresenta como a de menor dinamismo em termos de expansão territorial, porém, não menos relevante. Seu diferencial com relação às outras pode ser descrito por contemplar pequenos e médios produtores em seu quadro associativo. Possui 12 unidades distribuídas por municípios da região dos Campos Gerais e Norte Pioneiro paranaense. Além disso, também tem se expandido para a porção sudeste do estado de São Paulo, atuando, mais recentemente, com produtores de café.

A partir da análise e interpretação desses dados podemos verificar como se configura a dinâmica de ação territorial das cooperativas de imigrantes holandeses nas décadas recentes. Sempre contando com o apoio político e econômico do Estado, as cooperativas se sentiram seguras para lançar novas estratégias de mercado, resultando numa maior capilarização sobre o território. 


\section{ARTICULAÇÕES ENTRE O ESTADO E O COOPERATIVISMO AGRÍCOLA: UM ESTUDO SOBRE AS COOPERATIVAS DE IMIGRANTES HOLANDESES NOS CAMPOS GERAIS DO PARANÁ}

Além disso, esses resultados nos permitem afirmar que a Frísia, a Castrolanda e a Capal podem ser consideradas cooperativas híbridas (SERRA, 2008).

Serra (2008) defendeu esse conceito após estudar o processo de 'agigantamento' de algumas cooperativas paranaenses que, após a verticalização de algumas cadeias produtivas, expandiram suas infraestruturas de armazenamento e estocagem a níveis exorbitantes.

Em muitos casos, a produção de grãos que provêm somente do quadro associativo dessas cooperativas não é capaz de saturar toda a capacidade produtiva e de armazenamento de que dispõem. E visando aproveitar ao máximo o potencial de suas estruturas de armazenagem, as cooperativas que seguem o modelo híbrido passam a flexibilizar suas estratégias de atuação realizando contratos com produtores que não estão necessariamente vinculados ao seu quadro associativo. Trata-se de uma recente estratégia que tem sido reproduzida por diversas cooperativas agropecuárias com perfil agroindustrial que atuam com as commodities agrícolas voltadas ao mercado externo. As cooperativas deste estudo se encaixam nesse perfil.

\section{CONSIDERAÇÕES FINAIS}

Considera-se que o crescimento vertical e horizontal responsável pela dinamização das cooperativas Batavo/Frísia, Castrolanda e Capal foi fortalecido pelo apoio político do Estado brasileiro.

Além disso, as parcerias firmadas com instituições públicas (como bancos) e empresas do setor agropecuário permitiu que essas cooperativas fortalecessem suas atividades produtivas, criando condições para se tornarem agentes de organização do território paranaense.

Desde o momento em que o Estado projetou a imigração dos holandeses, alimentou a ideia de assegurar o desenvolvimento das colônias mediante a criação de cooperativas agropecuárias. Essa foi a 'via de mão dupla' encontrada pelo Estado para, além de consolidar o projeto migratório, se beneficiar da produção agrícola e do dinamismo econômico das cooperativas. Nos períodos de incerteza e dificuldade econômica, o Estado não se absteve e continuou conduzindo as cooperativas para rumos mais promissores. Nesse sentido, depositou nos bancos públicos a tarefa de fornecer o alicerce financeiro necessário à sustentação das cooperativas.

Com relação ao recorte temporal proposto nessa pesquisa, o trabalho demonstrou como a conjuntura neoliberal refletiu incisivamente sobre a ação territorial das cooperativas. A partir da década de 2000, se percebe que as cooperativas readequaram suas estratégias de produção buscando se alinhar a um novo perfil agroindustrial. Tais estratégias remetem ao processo de reestruturação produtiva que atingiu as cooperativas do grupo CCLPL, proporcionando uma atuação de mercado mais flexível e condizente com as estratégias de acumulação das corporações agroindustriais convencionais.

Partindo de uma visão geral sobre os resultados desse trabalho, se conclui que as cooperativas Batavo/Frísia, Castrolanda e Capal tiveram papel fundamental para dinamizar a economia e a divisão do trabalho no seu espaço de atuação. Para atingir esse patamar, acabaram se alinhando ao contexto estrutural do cooperativismo brasileiro se tornando cooperativas híbridas.

Ao introduzirem técnicas pioneiras no preparo do solo, como o plantio direto, promoveram uma agricultura aos moldes da Revolução Verde num solo que se caracteriza pela baixa aptidão agrícola. Sendo assim, contribuíram para acentuar os impactos socioambientais na região dos Campos Gerais, visto pelo grande nível de intervenção técnica e modificação natural, características que esse modelo de agricultura carrega.

Nesse sentido, pôde-se constatar que as cooperativas descendentes de imigrantes holandeses exerceram uma ação territorial que acompanhou o ritmo de reprodução do capital e a dinâmica do setor agrícola. Assim, reproduziram os interesses do Estado em seu projeto modernizador voltado à agricultura. A 


\section{ARTICULAÇÕES ENTRE O ESTADO E O COOPERATIVISMO AGRÍCOLA: UM ESTUDO SOBRE AS COOPERATIVAS DE IMIGRANTES HOLANDESES NOS CAMPOS GERAIS DO PARANÁ}

partir de práticas modernas de produção, aliado as características e as ruralidades do gênero de vida holandês, puderam agregar enorme simbolismo às marcas que lançaram ao varejo. Todo esse processo contou com a aplicação de recursos e políticas públicas do Estado.

Além disso, essas cooperativas passaram a se enquadrar nas tendências contemporâneas do mercado agrícola sem, entretanto, demonstrar preocupação sobre os impactos da adoção deste modelo sobre seu quadro associativo. Suas respectivas estratégias de atuação territorial se baseiam na utilização de seu enorme poder de cooptação de pequenos, médios e grandes produtores, para inseri-los junto a sua matriz produtiva e assim consolidar seu modelo de expansão.

Portanto, são cooperativas que reproduzem o movimento global do grande capital sobre o espaço rural, demonstrando um rebatimento dos processos globais na escala local. A transição do modelo de produção retratado pela reestruturação produtiva foi o exemplo mais notável desse processo. Por outro lado, mesmo introduzindo novas técnicas de produção e dinamizando economicamente a produção, não contribuíram para modificar os entraves da estrutura social da região onde se inserem.

\section{REFERÊNCIAS BIBLIOGRÁFICAS}

ALBUQUERQUE, Edu, S; AUED, Idaleto, M. Modernização e produção da miséria nos Campos Gerais do Paraná. Revista de História Regional, Ponta Grossa, no13, p.221-245, 2008.

CAZAROTTO, Simone; PEREIRA, Wellington. As Cooperativas de Produção Agroindustrial no Paraná e o Banco Regional de Desenvolvimento do Extremo Sul (BRDE) como seu Agente Indutor de Desenvolvimento. Revista Paranaense de Desenvolvimento, Curitiba, n.122, p.177-200, jan./jun. 2012.

COSTA, Daniele, R. F; FERREIRA, Yoshiya, N. Paraná: geopolítica imigrantista e a formação territorial. Geografia, Londrina, n.2, p.143-148, jul/dez, 1999.

CUNHA, Luiz A. G. O crédito rural $e$ a modernização da agricultura paranaense. Dissertação de Mestrado em História. Curitiba, 1986.

Confiança, capital social e desenvolvimento territorial. Revista RAEGA. Curitiba, n.4, p.49-60, 2000.

- Desenvolvimento rural e desenvolvimento territorial: o caso do Paraná Tradicional. UFRRJ: Tese de Doutorado em Geografia. Seropédica, 2003.

Cooperar é preciso, viver também: a Batavo Cooperativa Agroindustrial e sua obra nos Campos Gerais. In: CHAVES, Niltonci B. (org). Imigrantes - Immigranten. História da imigração holandesa na região dos Campos Gerais, 19112011. Ponta Grossa, Estúdio texto, 2011, p.127145.

FAJARDO, Sergio. Territorialidades corporativas no rural paranaense. Guarapuava: Editora da Unicentro, 2008.

GALLAS, Alfredo, O; GALLAS, Fernanda, D; Holandeses no Brasil: 100 anos de imigração positiva. São Paulo: ed do autor, 2012.

GONÇALVES, Ricardo, C. A evolução do cooperativismo agropecuário no Brasil. UFRGS: Trabalho de Conclusão de Curso, Porto Alegre, 2012.

LAUBSTEIN, Fernanda C. A Ruralidade ontem e hoje: uma análise do rural na contemporaneidade. Revista Aurora, v. 4, n. 2, agora. 2011.

LOPES, Alan P. Território usado e recursos hídricos: o uso da água na produção de flores e plantas ornamentais em Holambra/SP. 2015. 164 f. Dissertação - (mestrado) - Universidade Estadual Paulista, Instituto de Geociências e 


\section{ARTICULAÇÕES ENTRE O ESTADO E O COOPERATIVISMO AGRÍCOLA: UM ESTUDO SOBRE AS COOPERATIVAS DE IMIGRANTES HOLANDESES NOS CAMPOS GERAIS DO PARANÁ}

Ciências Exatas, 2015. Disponível em: <http://hdl.handle.net/11449/138538>.

MAACK, R. Notas preliminares sobre clima, solos e vegetação do Estado do Paraná. Curitiba, Arquivos de Biologia e Tecnologia, v.II, p.102-200, 1948.

OCEPAR, Organização das Cooperativas do Paraná. O cooperativismo no Paraná e o Sistema OCEPAR. Disponível em: http://www.paranacooperativo.coop.br/ppc/ind ex.php/sistema-ocepar/2011-12-05-11-2942/2011-12-05-11-42-54

PADILHA, Wilian. O papel do crédito no desenvolvimento das cooperativas agropecuárias. UNIOESTE: Dissertação de Mestrado em Geografia, Francisco Beltrão, 2014.

PADIS, Pedro, C. Formação de uma economia periférica: o caso do Paraná. Curitiba, IPARDES, 2006.

SCHNEIDER, João E. O cooperativismo agrícola na dinâmica social do desenvolvimento periférico dependente: o caso brasileiro. In: LOUREIRO, Maria R. Cooperativas agrícolas e capitalismo no Brasil. São Paulo, Cortez, 1981.

SERRA, Elpídio. O cooperativismo híbrido e suas formas de atuação no Paraná. Revista Agrária, São Paulo. n.8, p.4-22, 2008.

A participação do Estado na formação e desenvolvimento das cooperativas agrícolas no Brasil. Campo-território: revista de geografia agrária, v.8, n.16, p.6-37, ago, 2013. 